\title{
Perspektywy udziału firm spawalniczych działających w branży energetycznej w budowie pierwszej elektrowni jądrowej w Polsce
}

\author{
Prospects for participation of operating \\ in the energy sector welding companies in the construction \\ of the first nuclear power plant in Poland
}

\section{Streszczenie}

Przedstawiono warunki stosowania uznanych przepisów i norm światowych podczas budowy pierwszej elektrowni jądrowej w Polsce. Stwierdzono, że najbardziej prawdopodobnym jest stosowanie odpowiednich sekcji jednego z dwóch kodów: AFCEN lub ASME. Przytoczono najważniejsze urządzenia i konstrukcje spawane elektrowni jądrowej oraz przeprowadzono analizę możliwości oraz warunki techniczne i jakościowe wykonania tych wyrobów lub ich części przez krajowe podmioty gospodarcze.

Słowa kluczowe: reaktor jądrowy; obudowa bezpieczeństwa; system zapewnienia jakości; elektrownia jądrowa

\begin{abstract}
Conditions of use of recognized codes and standards during the construction of the first nuclear power plant in Poland are presented. It has been found that the most likely is the application of the relevant sections of one of the two codes: AFCEN or ASME. Major equipment and welded metal construction of nuclear power plants as well as an analysis of the possibilities, and technical and qualitative conditions for the production of these products or their parts by domestic companies are described.
\end{abstract}

Keywords: nuclear pressure vessel; piping; liner; quality management system; nuclear power plant

\section{Wstęp}

Program Polskiej Energetyki Jądrowej (PPEJ) z dnia 28 stycznia 2014 roku zakłada, że pierwsza elektrownia jądrowa w Polsce powinna powstać około 2024 roku. W chwili obecnej jest już jednak pewne, że termin ten ulegnie przesunięciu, co nie zmienia faktu, że przygotowywania do budowy elektrowni trwają, także w obszarze analizy wymagań jądrowych norm technicznych oraz przepisów dotyczących systemów zapewnienia jakości. Kluczowym w przyśpieszeniu tych przygotowań byłby wybór dostawcy technologii jądrowej, gdyż typ reaktora (reaktor wodny ciśnieniowy - PWR lub reaktor wodny wrzący - BWR) oraz kraj pochodzenia technologii jądrowej zdefiniuje zestaw przepisów technicznych i jakościowych zawierających stosowne wymagania szczegółowe. Decyzja o wyborze dostawcy technologii jądrowej jeszcze nie zapadła, ale mimo to nie ulega wątpliwości, że niezależnie od wyniku przetargu, określona część prac związanych z budową elektrowni jądrowej oraz dostawą części urządzeń i świadczeniem usług (w tym NDT) będzie podzlecona firmom krajowym. Wydaje się zatem zasadnym i zdecydowanie celowym omówienie zakresu prac w ramach ewentualnych zleceń, jak i niektórych wymagań przepisów, które należałoby spełnić.

\section{Przepisy techniczne i jakościowe}

W związku z brakiem działających elektrowni jądrowych, Polska nie posiada własnych przepisów i norm dotyczących ich budowy i eksploatacji. Projekt rozporządzenia Ministra Gospodarki w sprawie warunków technicznych dozoru technicznego dla urządzeń technicznych lub urządzeń podlegających dozorowi technicznemu w elektrowni jądrowej zakłada, że do projektowania i budowy urządzeń mechanicznych oraz konstrukcji obudów bezpieczeństwa elektrowni jądrowych zaliczonych do klas bezpieczeństwa dopuszcza się stosowanie następujących uznanych przepisów lub odpowiednich ich sekcji, jak również norm: AFCEN (Francja), JSME (Japonia), CSA (Kanada), KEPIC (Korea Południowa), KTA (Niemcy) oraz ASME (USA).

Zważywszy jednak na to, że wśród potencjalnych dostawców technologii jądrowej najczęściej wymienia się firmy: AREVA (ERP), GE Hitachi (ABWR) oraz Westinghouse (AP1000), najbardziej prawdopodobnym będzie stosowanie w Polsce norm amerykańskich ASME lub francuskich AFCEN. Pod uwagę są brane także technologie firm KEPCO (APR1400) z Korei oraz AECL (ACR-1000) z Kanady posiadających własne normy jądrowe, które jednak bazują na wymaganiach kodu ASME.

Dr inż. Jerzy Niagaj, prof. nzw. - Instytut Spawalnictwa, Pełnomocnik ds. Energetyki Jądrowej.

Autor korespondencyjny/Corresponding author: jerzy.niagaj@is.gliwice.pl 
W przepisach ASME B\&PVC sekcją opisującą wymagania w zakresie urządzeń jądrowych jest ASME sekcja III [1]. Sekcja ta wraz z innymi, do których się odwołuje (np. II, V, IX lub $\mathrm{XI}$ ), jest stosowana podczas budowy elektrowni jądrowych nie tylko w USA, lecz również w wielu innych krajach na świecie.

Gdyby dostawcą technologii jądrowej w Polsce był francuski koncern AREVA, wymagania byłyby zawarte w normie AFCEN, w którym najistotniejszymi z punktu widzenia zagadnień spawalniczych są sekcje RCC-M [2] oraz RCC-CW [3]. Kod AFCEN jest od około 40 lat rozwijana we Francji w sposób niezależny od normy ASME, co przyczyniło się do zdecydowanie innej jego struktury, a w niektórych przypadkach również zawartości. Nie zmienia to jednak faktu, iż odpowiednie sekcje obydwu norm (AFCEN i ASME) są do siebie bardzo podobne.

W przypadku systemów zapewnienia jakości, ww. projekt rozporządzenia Ministra Gospodarki zakłada możliwość stosowania następujących uznanych specyfikacji technicznych: IAEA GS-R-3 [4]; AFCEN (Francja); JEAC 4111 (Japonia); N28612 (Kanada); KEPIC, Area - QA (Korea Południowa); KTA 1401 (Niemcy); ASME NQA-1 lub 10CFR50 Appendix B (USA).

Przepisy ASME B\&PVC w zakresie systemów zapewnienia jakości dla zastosowań jądrowych zakładają stosowanie wymagań normy ASME NQA-1 [5]. Japonia, Korea Południowa i Kanada posiadają własne normy dotyczące systemów zapewnienia jakości, które jednak uwzględniają zalecenia GS-R-3 i w wielu punktach są podobne do wymagań zawartych w normie ASME NQA-1. Z kolei w przypadku normy AFCEN wymagania w zakresie systemów zapewnienia jakości również bazują na zaleceniach IAEA GS-R-3, ale także wymaganiach normy EN ISO 9001 [6] oraz dokumentu NSQ-100 [7].

\section{Konstrukcje i urządzenia spawane elektrowni jądrowych}

Elektrownia jądrowa jest obiektem złożonym, który niezależnie od typu reaktora (PWR lub BWR) składa się z dwóch części: jądrowej i konwencjonalnej, nazywanych również w publikacjach technicznych wyspami: wyspa jądrowa i wyspa turbinowa lub konwencjonalna.

\section{a) wyspa turbinowa}

Wyspa turbinowa w przypadku obydwu typów reaktorów składa się z podobnego zestawu podstawowych urządzeń, wśród których najważniejszymi są: turbina; skraplacz; różnej wielkości zbiorniki ciśnieniowe i magazynowe, w tym podgrzewacze, separatory, wymienniki ciepła, demineralizatory, zasobniki wody chłodzącej itd.; rurociągi technologiczne pary i wody chłodzącej wraz z układami wsporczymi; pompy i zawory oraz układy grzewcze, próżniowe i filtrowentylacyjne (HVAC) o różnym przeznaczeniu.

Podstawowym elementem wyspy turbinowej jest oczywiście turbina, której głównymi dostawcami w Europie i nie tylko, są firmy Alstom i Siemens. Siemens oferuję dostawę turbiny STT-9000 o mocy 1720 MW składającej się z jednej sekcji wysokoprężnej i trzech niskoprężnych o łącznej długości 68,8 m i maksymalnej średnicy wirnika z łopatkami $6720 \mathrm{~mm}$ oraz o następującej wadze poszczególnych elementów: wirnik HP = 92,5 ton, turbina HP $=378,8$ ton, wirnik LP $(1)=340$ ton oraz turbina LP $(1)=1268$ ton [8]. W skład zespołu turbinowego wchodzi ponadto 6 skraplaczy o wadze ok. 250 ton każdy.

$Z$ kolei Alstom oferuje turbinę ARABELLETM o mocy 1750 MW [9], której gotowy wirnik waży 120 ton, a odkuwka do jego wykonania ok. 200 ton. Turbina ta jest krótsza i lżejsza niż turbiny poprzedniej generacji dla elektrowni jądrowych, co nie oznacza, że proces jej produkcji jest łatwiejszy. b) wyspa jądrowa

W przypadku wyspy jądrowej sytuacja jest nieco inna, gdyż zestaw urządzeń podstawowych jest uzależniony od typu reaktora: PWR lub BWR. Przy porównaniu reaktorów PWR (EPR -rys. 1 i AP1000 -rys. 2) z reaktorem BWR (ABWR -rys. 3) widać, że $w$ reaktorach PWR występują elementy nie stosowane $w$ reaktorach BWR, a mianowicie: wytwornice pary, stabilizator ciśnienia, rurociągi główne obiegu pierwotnego, pompy układu chłodzenia obiegu pierwotnego. Nie występują natomiast pompy recyrkulacyjne, stosowane w reaktorach BWR.

Pozostałe elementy mimo różnic w konstrukcji, wielkości i ilości są takie same: reaktor wraz ze strukturami wewnętrznymi; napędy prętów sterujących; zbiorniki wody chłodzącej; wymienniki ciepła w różnych układach technologicznych; zbiorniki technologiczne (ciśnieniowe i magazynowe) i baseny wodne; rurociągi (pary, wody, chłodzenia, kontroli itd.) wraz z wspornikami; pompy i zawory oraz układy grzewcze, próżniowe i filtrowentylacyjne (HVAC).

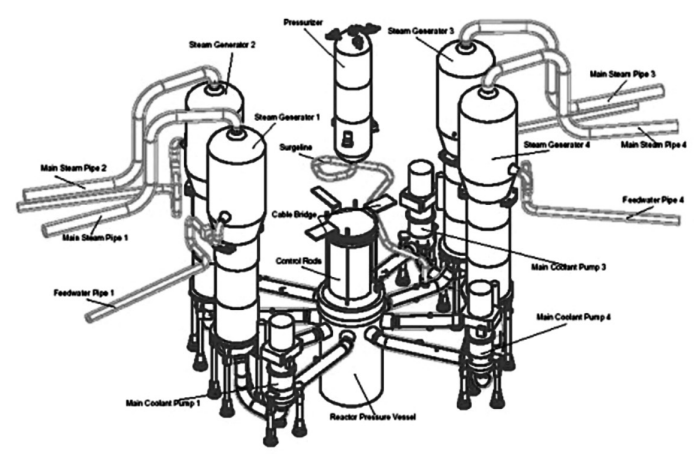

Rys. 1. Schemat obiegu pierwotnego reaktora EPR ${ }^{\mathrm{TM}}$ [10]

Fig. 1. The arrangement of the EPR ${ }^{\mathrm{TM}}$ primary circuit

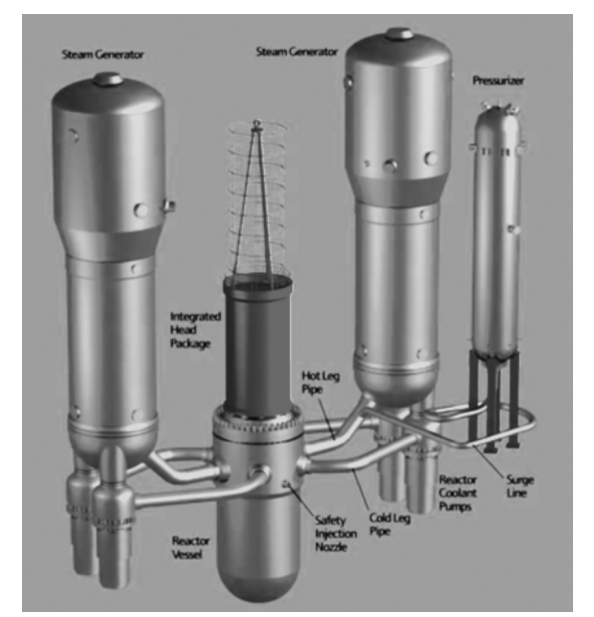

Rys. 2. Schemat obiegu pierwotnego reaktora AP1000 [11]

Fig. 2. The arrangement of the AP1000 primary circuit

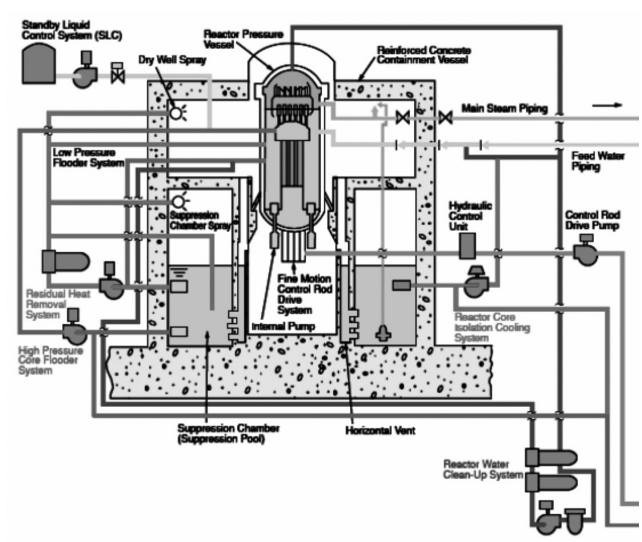

Rys. 3. Schemat wyspy jądrowej reaktora ABWR [12]

Fig. 3. Diagram of the ABWR nuclear island 


\section{c) obudowa bezpieczeństwa}

Niezależnie od typu reaktora (PWR lub BWR), zbiornik ciśnieniowy oraz inne główne urządzenia i układy jądrowe (np. wytwornica pary, stabilizator ciśnienia, pompy, główne rurociągi, zbiorniki z wodą do chłodzenia itd.) są umieszczane w budynku reaktora, który bez wątpienia jest najważniejszym obiektem elektrowni jądrowej, gdyż jednym z podstawowych jego zadań jest ochrona personelu obsługującego i otoczenia przed promieniowaniem, jak również reaktora i innych ważnych urządzeń przed uszkodzeniem zewnętrznym i przedostaniem się na zewnątrz substancji promieniotwórczych. W związku z powyższym, obudowa bezpieczeństwa reaktora jest projektowana i obliczana w taki sposób, aby przez $60 \div 70$ lat wytrzymywała wstrząsy sejsmiczne, ataki terrorystyczne (np. upadek samolotu), uderzenia tsunami oraz oddziaływanie wielu innych czynników (np. tornado, huragan, śnieżyca itd.), jak również zapewniała całkowitą szczelność.

Obudowa bezpieczeństwa budynku reaktora współczesnych elektrowni jądrowych jest konstrukcją złożoną, która składa się z płaszcza metalowego oraz struktury żelbetowej o różnej konfiguracji i budowie w zależności od typu reaktora i dostawcy technologii jądrowej.

Obudowa bezpieczeństwa reaktora EPR firmy AREVA jest strukturą budowlaną, która składa się z dwóch żelbetowych współosiowych struktur pierścieniowych z przestrzenią powietrzną pomiędzy nimi oraz wewnętrznego szczelnego płaszcza metalowego o grubości ścianki $6 \mathrm{~mm}$ (rys. 4). Wewnętrzna struktura budowlana jest wykonana z betonu sprężonego w postaci cylindrycznej ściany zwieńczonej eliptyczną kopułą z podłożem ze zbrojonego betonu. Zewnętrzna natomiast ma postać zbrojonej cylindrycznej ściany opierającej się na tym samym podłożu wraz ze zbrojoną kopułą i służy jako ochrona przed zagrożeniami zewnętrznymi. Wymagania dotyczące projektowania, wytwarzania i badania zarówno struktur żelbetowych, jak i płaszcza metalowego zostały przedstawione w przepisach AFCEN RCC-CW [3].

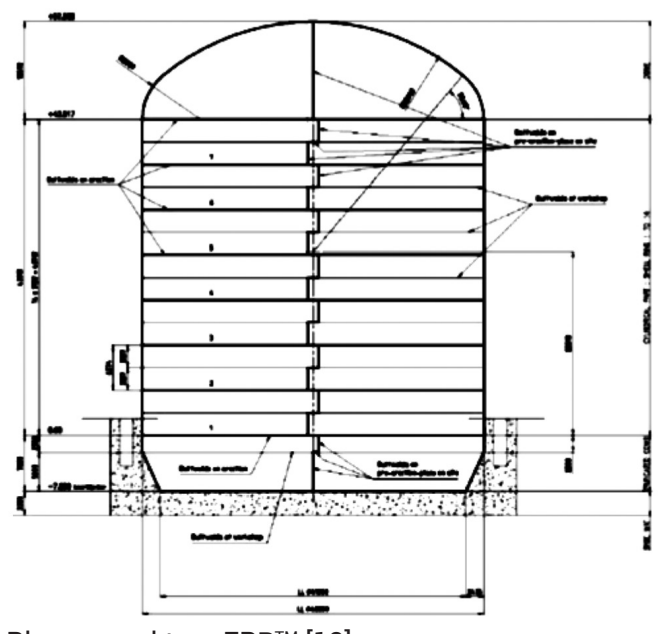

Rys. 4. Płaszcz reaktora EPR ${ }^{\mathrm{TM}}$ [13]

Fig. 4. The steel liner of the EPR ${ }^{\mathrm{TM}}$

W przypadku reaktora AP1000 (typ PWR) obudowa bezpieczeństwa składa się z wewnętrznego płaszcza stalowego (rys. 5) oraz panelowej zewnętrznej struktury stalowo-betonowej (rys. 6), którą do budowy budynku reaktora jądrowego zastosowano po raz pierwszy w Japonii w 1996 roku. Grubość blachy w dolnej części cylindrycznej wewnętrznego płaszcza stalowego obudowy reaktora AP1000 wynosi 1,875 cala $(47,625 \mathrm{~mm})$, a w pozostałej 1,75 cala (44,45 mm). Grubość blach tworzących części zamykające: dolną i górną wynosi 1,625 cala $(41,275 \mathrm{~mm})$. Odpowiednio uformowane blachy ze stali w gatunku ASME SA-738, Grade $B$ są dostarczane na plac budowy, gdzie łączy się je za pomocą metod spawalniczych, głównie w sposób zmechanizowany, w celu powstania dennicy, pierścieni i kopuły.

Gotowe fragmenty płaszcza stalowego są po kolei łączone ze sobą za pomocą spawania podczas wznoszenia budynku reaktora. Montaż płaszcza zaczyna się od części dolnej, którą ustawia się na specjalnej stalowej konstrukcji wsporczej. Kolejne pierścienie i kopuła są przyspawywane do części dolnej w miarę postępu prac montażowo-budowlanych.

Elektrownia z reaktorem AP1000 jest budowana w sposób modułowy, który zakłada wykonanie i montaż modułów różnego typu (konstrukcyjne, mechaniczne i budowlane) i stopnia złożoności. Moduły konstrukcyjne, tworzące ściany i podłogi pomieszczeń i zbiorników wodnych zarówno wewnątrz, jak i na zewnątrz płaszcza obudowy reaktora, składają się głównie z blach, kształtowników i kołków stalowych, które po wykonaniu w warsztacie, a następnie scaleniu na placu budowy i zamontowaniu w miejscu przeznaczenia są w większości przypadków zalewane betonem. Ww. moduły cechują się różną wielkością, co powoduje, że w warunkach warsztatowych są wykonywane tylko mniejsze z nich lub poszczególne fragmenty modułów wielkogabarytowych, które następnie są scalane na placu budowy.

Z dokumentacji technicznej AP1000 Design Control Document firmy Westinghouse wynika, że do wykonania płaszcza stalowego wraz z przepustami i śluzami dla przemieszczania urządzeń i personelu ma zastosowanie kod ASME Section III, Division 1 [1]. Z kolei panelowy zewnętrzny płaszcz bezpieczeństwa, konstrukcja wsporcza wewnętrznego płaszcza stalowego obudowy oraz stalowe moduły konstrukcyjne są wykonywane w oparciu o wymagania normy ANSI/AISC N690 [16].

W przypadku reaktora ABWR firmy GE Hitachi (typ BWR) obudowa bezpieczeństwa składa się ze struktury żelbetowej oraz wewnętrznego płaszcza stalowego (rys. 7), podobnie, jak ma to miejsce w przypadku reaktora EPR firmy AREVA (typ PWR). Do wykonania płaszcza metalowego obudowy reaktora ABWR stosuje się stal nierdzewną i węglową. Ze stali nierdzewnej 304L, według ASME SA-240, wykonuje się fragment dolny płaszcza, gdyż jest on w większym stopniu niż część górna narażony na oddziaływanie czynnika korozyjnego. Fragment górny wykonuje się natomiast ze stali węglowej w gatunku ASME SA-516 Gr. 70 o grubości $6,35 \mathrm{~mm}$. Kopuła oraz fragment obudowy ze stali węglowej stanowiący część górnego modułu ma grubość 31,8 mm. Interesującym szczegółem wykonawczym jest to, że do 98 $\%$ prac spawalniczych płaszcza obudowy wykonywanych jest w sposób zmechanizowany.

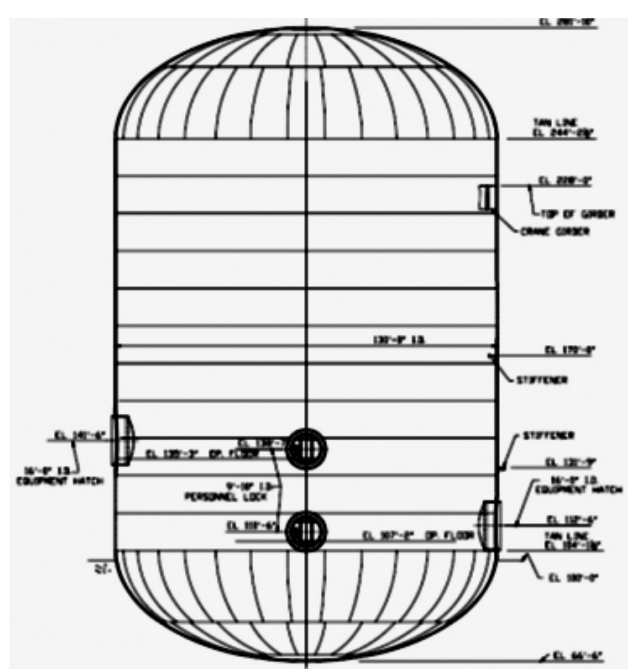

Rys. 5. Wewnętrzny płaszcz stalowy reaktora AP1000 firmy Westinghouse [14]

Fig. 5. The inner steel liner of the AP1000 


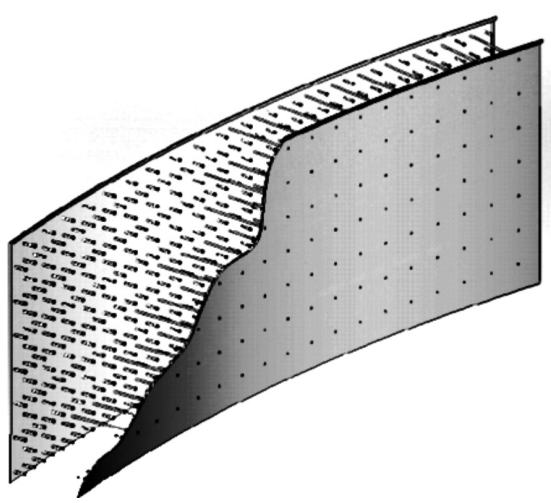

Rys. 6. Struktura panelu obudowy zewnętrznej części reaktora AP1000 [15] Fig. 6. The structure of the panel outer containment of the reactor AP1000

Budowa elektrowni jądrowej z reaktorem ABWR przebiega w sposób modułowy, co powoduje, że w jednym module mogą znajdować się stalowe struktury konstrukcyjne, układy mechaniczne i struktury budowlane:

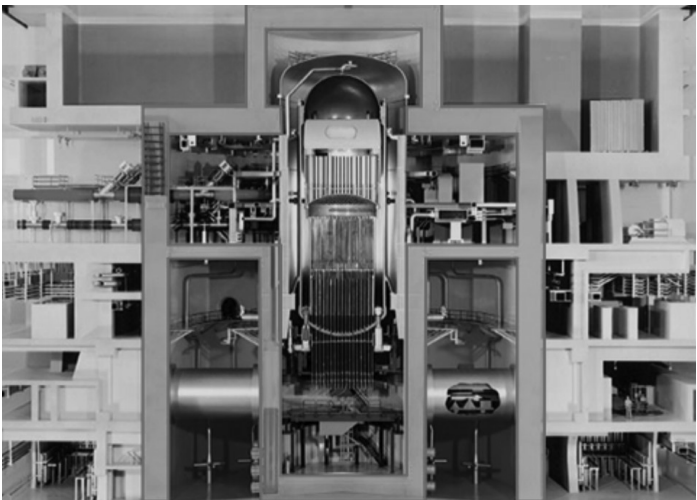

Rys. 7. Budynek reaktora ABWR firmy GE Hitachi [17]

Fig. 7. ABWR RCCV (Reinforced Concrete Containment Vessel)

W związku z różną konstrukcją i klasą bezpieczeństwa poszczególne stalowe elementy konstrukcyjne budynku reaktora ABWR są wykonywane w oparciu o wymagania ASME Sect. III, Division 2 i ASME Sect. III, Division 1 MC oraz normy ANSI/AISC N690 [16].

\section{Wnioski}

W związku ze stosowaniem materiałów promieniotwórczych jako paliwa do wytwarzania ciepła przetwarzanego następnie na energie elektryczną, elektrownia jądrowa jest obiektem, w którym zagadnienia bezpieczeństwa stoją na pierwszym miejscu. Szczególna troska o bezpieczną pracę elektrowni powoduje, że zarówno na etapie projektowania i budowy, jak i podczas długotrwałej eksploatacji, konieczne jest przestrzeganie rygorystycznych przepisów, i norm, które obejmują nie tylko zagadnienia techniczne, lecz również jakościowe.

Analiza wykazała, że istnieje duże prawdopodobieństwo, że normą stosowaną podczas budowy elektrowni w Polsce będzie jedna z dwóch: amerykański kod ASME lub francuski AFCEN. Wymagania zawarte w odpowiednich sekcjach tych norm są bardzo podobne, ale jednocześnie charakteryzują się znacząco różniącą się strukturą wewnętrzną oraz bazują na różnym zestawie norm i przepisów: AFCEN opiera się na normach europejskich i międzynarodowych typu EN oraz EN ISO, natomiast ASME odwołuje się do amerykańskich przepisów typu: ASTM, AWS, ANSI/AISC, ACI i inn.

Przedstawiona analiza budowy elektrowni jądrowej pod katem stosowanych konstrukcji i wyrobów spawanych, jak również istniejące aktualnie możliwości produkcyjne i doświadczenia przemysłu krajowego w dziedzinie energetyki jądrowej wskazuje, że najbardziej prawdopodobnym obszarem spodziewanego udziału firm polskich w budowie elektrowni byłoby wykonanie: obudowy bezpieczeństwa reaktora lub jej fragmentów, różnego rodzaju stalowych elementów konstrukcyjnych, niektórych fragmentów rurociągów (w zależności od wielkości i typu reaktora ich łączna długość szacuje się na 150 200 km, w tym ponad połowa ze stali nierdzewnych) i instalacji HVAC oraz różnego rodzaju małych i średnich zbiorników ciśnieniowych (np. wymienniki ciepła, podgrzewacze), jak również poszycia basenów i zbiorników wodnych ze stali nierdzewnej.

Powyższe stwierdzenie dotyczące możliwości wykonania stalowej obudowy bezpieczeństwa reaktora przez podmioty krajowe opiera się o to, że niezależnie od dostawcy technologii jądrowej i użytych norm, do wykonania elementów metalowych obudowy są przede wszystkim zalecane powszechnie znane i szeroko stosowane stale węglowe normalizowane lub na urządzenia ciśnieniowe w postaci blach, rur, prętów, kołków i kształtowników, z których przetwarzaniem (cięciem, gięciem, spawaniem) krajowe firmy z branży metalowej powinny sobie bez trudu poradzić [18]. Podstawowym zadaniem do rozwiązania wydaje się zatem być posiadanie: certyfikowanego systemu zapewnienia jakości uwzględniającego specyficzne wymagania jądrowe, sprawdzonych i uznanych technologii produkcyjnych (przede wszystkim spawalniczych), personelu o potwierdzonych kwalifikacjach, jak również udowodnienie, że firma posiada doświadczenie w wykonaniu konstrukcji dla obiektów jądrowych lub konstrukcji o podobnej skali odpowiedzialności i złożoności oraz jest w stanie zapewnić terminowość wykonania zleceń.

Z technicznego punktu widzenia, bazujące na procesach spawalniczych firmy krajowe byłby w stanie wykonać na rzecz elektrowni jądrowej: rurociągi i ich wsporniki, sporą część małych i średnich urządzeń ciśnieniowych oraz konstrukcji stalowych obudowy bezpieczeństwa i HVAC. Udział tych firm w wykonywaniu tych konstrukcji i urządzeń jest jednak uwarunkowany posiadaniem przez zakład m.in.: specjalnego systemu zapewnienia jakości, doświadczeń w dziedzinie energetyki jądrowej lub o zbliżonej skali odpowiedzialności, personelu spawalniczego i NDT o odpowiednich kwalifikacjach oraz sprawdzonych technologii spawalniczych (WPS, WPQR).

\section{Artykuł powstał w ramach projektu wspótfinansowanego ze środków Ministerstwa Energii w ramach wdrażania energetyki jądrowej w Polsce.}

\section{Literatura}

[1] ASME B\&PV, Section III „Rules for construction of nuclear facility components". American Society of Mechanical Engineers, New York, 2008
[2] AFCEN RCC-M „Design and Construction Rules for Mechanical Components of PWR Nuclear Islands", 2012 Edition. 
[3] AFCEN RCC-CW „Rules for Design and Construction of PWR Nuclear Civil Works". 2015 Edition.

[4] "The Management System for Facilities and Activities", IAEA, Series No. GS-R-3, published Friday, July 21, 2006.

[5] ASME NQA-1-2015 „Quality Assurance Requirements for Nuclear Facility Applications".

[6] PN-EN ISO 9001:2015-10 „Systemy zarządzania jakością - Wymagania”.

[7] NSQ-100 „Nuclear Safety and Quality Management System - Requirements", 2011.

[8] "Siemens. The Turbine Island for Nuclear Power Plants", Warszawa, 1-2 czerwca 2006.

[9] „ARABELLETM Steam Turbine for Nuclear Power Plant", ALSTOM, 2012.

[10] P. Varpasuo, "The seismic response and floor spectra of OL3 NPP buildings in Finland", 18th International Conference on Structural Mechanics in Reactor Technology (SMiRT 18), Beijing, China, 7-12 August 2005.

[11] P. Gaio, „AP1000: The PWR Revisited”, IAEA International Conference on Opportunities and Challenges for Water Cooled Reactors in the 21st Century, Viena, Austria, 27-30 October 2009.
[12] "Advanced Boiling Water Reactor. The only generation III+ Reactor in Operation today", Hitachi-GE Nuclear Energy, Ltd., Catalog No.: 83ZZ1-0022 R0, 2013.

[13] V. Moucquot-Laiho, „Olkilouto 3 Project”, AREVA Suppliers` Day, Warszawa, 4 Października 2011.

[14] Westinghouse AP1000 Design Control Document Rev. 19 - Tier 2 Chapter 3 - Design of Structures, Components, Equip. \& Systems - 3.8 Design of Category I Structures.

[15] Westinghouse AP1000 Design Control Document Rev. 19 - Tier 2 Chapter 3 - Design of Structures, Components, Equip. \& Systems - Appendix $3 \mathrm{H}$ Auxiliary and Shield Building Critical Sections.

[16] ANSI/AISC N690 "Specification for Safety-Related Steel Structures for Nuclear Facilities".

[17] http://www.hitachi-hgne-uk-abwr.co.uk/reactor-building.html

[18] J. Niagaj, „Konstrukcje stalowe obudowy bezpieczeństwa reaktora jądrowego", Wytyczne wspomagające działania przedsiębiorstw krajowych w budowie elektrowni jądrowych, W/ME/DEJ/IS/02/15, Wydanie 1, Warszawa, 2015. 